\title{
Port-Site Metastasis after Laparoscopic Surgery for Urological Malignancy: Forgotten or Missed
}

\author{
N. Kadi, ${ }^{1}$ M. Isherwood, ${ }^{1}$ M. Al-Akraa, ${ }^{2}$ and S. Williams ${ }^{1}$ \\ ${ }^{1}$ The Urology Department, Royal Derby Hospital, Derby, DE22 3NE, UK \\ ${ }^{2}$ The Urology Department, the Royal Free Hospital, London, NW3 2QG, UK
}

Correspondence should be addressed to N. Kadi, nourdin@hotmail.co.uk

Received 30 April 2011; Revised 10 October 2011; Accepted 16 January 2012

Academic Editor: Walid A. Farhat

Copyright $\odot 2012$ N. Kadi et al. This is an open access article distributed under the Creative Commons Attribution License, which permits unrestricted use, distribution, and reproduction in any medium, provided the original work is properly cited.

\begin{abstract}
Purpose. Port-site metastasis has been a concern with the common use of laparoscopy in urologic oncology. We conducted this study to provide a review of port-site metastases reported after the laparoscopy in managing urologic malignancies, possible contributing factors and preventative measures. Materials and Methods. An electronic search of MEDLINE using the combined MESH key words "port-site metastasis" and "Urology". Results. 51 articles addressing port-site metastasis after laparoscopic surgery for urolo $\neg$ gical malignancy were identified. Conclusion. Port-site metastasis after laparoscopic surgery for urolo $\neg$ gical malignancy is rare. The incidence is comparable to the rate for surgical wound metastases.
\end{abstract}

\section{Introduction}

In recent years, with the widespread use of laparoscopy to treat an ever-increasing number of urologic malignancies, questions have been raised about the oncologic safety of this surgical approach [1]. Currently, a large number of specialized centres around the world perform laparoscopy for urologic cancer $[2,3]$. Nevertheless, local recurrence and port-site metastasis remain a concern [4].

Port-site metastases, though rare, have been extensively documented for other gynaecological and GI malignancies. When they occur, they often do so in the presence of advanced disease, but it is not uncommon for them to occur in isolation $[5,6]$. Concern has been expressed that laparoscopic surgery might adversely affect the long-term outcomes by increasing the risk of port-site and peritoneal seeding.

The first known report of a port-site metastasis was by Dobronte and associates [7] in 1978. The authors reported implantation of malignant ovarian cystic adenoma in penetration sites of the pneumo-needle and trocar. Some specific procedures and tumors have been associated with a higher incidence of portsite metastasis or tumor seeding; however, the precise incidence of port-site metastasis and its aetiology and pathogenesis have not been well defined in urologic laparoscopy [8].

Port-site metastases is a multifactorial phenomenon with an as-yet undetermined incidence. Etiological factors include natural malignant disease behavior [9], host immune status [9], local wound factors [9], laparoscopy-related factors such as aerosolization of tumor cells (the use of gas, type of gas, insufflation and desufflation, and pneumoperitoneum) [9], and sufficient technical experience of the surgeons and operating team [9] (adequate laparoscopic equipment, skill, minimal handling of the tumor, surgical manipulation and wound contamination during instruments change, organ morcellation, and specimen removal) [9].

\section{Materials and Methods}

An electronic search of MEDLINE of the published literature up to 2010 was carried out using the combined MESH key words "port-site metastasis" and "Urology."

Duplicate references, as well as repeated references to the same data sets, were removed. The articles and case reports directly addressing port-site metastasis after laparoscopic surgery for urological malignancy were reviewed. 
Articles were selected and categorized by topic into incidence, aetiology, pathophysiology, and possible preventative measures.

\section{Results}

Table 1 showed the case reports found on MEDLINE search of the published literature up to 2010 recovered 51 for the MESH words "port-site metastasis" and "Urology."

Etiological factor has been categorised in three main categories: tumour related, wound related, and surgical technique related. Surgical technique related factors have been categorised in two main categories: manipulation is the principal factor acting in tumour dissemination. Extraction of the surgical specimen is determined by the surgeon. The possible preventive measure has been categorised in two main categories: active measures and measures for reducing the risk of laparoscopic port-site metastasis in urological surgery.

\section{Discussion}

Laparoscopic surgery is rapidly gaining widespread acceptance among urologists, including extensive application in malignant conditions [9]. The incidence of tumour seeding in general laparoscopic surgery ranges from $0.8 \%$ to $21 \%$ $(8,9)$. However, most authors report an incidence of $0.5 \%$, comparable to the rate for surgical wound metastases $(0.8 \%-$ $1.6 \%)$ in conventional open methods [9-11]. In recent years, several reports of port-site metastasis and tumor seeding have been published. Tsivian and Sidi [9] alone reported nine cases of port-site metastases after urologic laparoscopy, and Rassweiler and colleagues [10] published eight local recurrences observed in 1098 laparoscopic procedures for urologic malignancies. Recently, in an international survey of 19 urologic laparoscopic centres performing a total of 18,750 laparoscopic procedures for urologic malignancies, tumour seeding was reported in 13 cases $(0.1 \%)$ [8].

Various theories tried to explain metastasis development at laparoscopic port site [12]. Factors can be divided into three categories: tumor related, wound related, and surgical technique related [4].

Tumor-related factors [8-10]: biological aggressiveness of the tumor, represented by grade and stage, could play a decisive role in possible tumor seeding determination, explaining why grade 2 and 3 transitional cell carcinomas represent the majority of port-site metastases in urological procedures [8-10].

Wound-related factors [11-17]: local and systemic immune response to the pneumoperitoneum has been suggested. Its physiopathological mechanism has yet to be completely defined. There is a tendency towards systemic preservation of the immune system and towards immune depression of the peritoneum during laparoscopic insufflation demonstrated by macrophage function alteration [11-17].
Surgical technique-related factors [9, 18-30]: manipulation is the principal factor acting in tumor dissemination. Extraction of the surgical specimen is determined by the surgeons $[9,18-30]$.

However, it is logical to assume that morcellation of the specimen increases tumor seeding $[5,6,15]$. The direct dissemination of tumor cells from contaminated material or from extraction with an unclosed bag is well documented $[5,6,15]$. The observance of a large number of tumor cells at excessively manipulated ports supports this hypothesis as well as observance of greater number of malignant cells at port sites used by the surgeon compared with those used by assistants $[5,6,15]$.

The problem is influenced to some extent by surgeon and operating team experience $[9,31-37]$, and, therefore, it could be partially prevented $[9,31-37]$.

Port-site recurrence of tumour is a particular, and increasingly recognized [9, 31-37], drawback. certain measures have been suggested to prevent urologic port-site metastasis [9, 31-37], including (1) sufficient technical preparation, (2) avoidance of laparoscopic surgery if ascites ispresent [9, 31-37], (3) trocar fixation with avoidance of gas leakage along the trocar, (4) avoidance of tumorboundary violation [9, 31-37], (5) cautious consideration of morcellation, (6) use of an impermeable bag if morcellation is done $[9,31-37],(7)$ use of a bag for intact specimen removal, (8) drainage placement if needed before abdominal deflation [9, 31-37], (9) povidone-iodine irrigation of the laparoscopic instruments, trocar, and port-site wounds [9, $31-37]$, and (10) suturing $10 \mathrm{~mm}$ trocar wounds [9, 3137]. Povidone-iodine irrigation has been questioned, and peritoneal irritation secondary to this agent must not be underestimated [9, 31-37]. Regarding suggestion 10, Burns and coworkers [21] demonstrated on an animal model that portsite tumor implantation was significantly increased $(P<0.03)$ when only skin was closed compared with closure of all three layers [21]. The authors proved that closure technique may influence the rate of port-site tumor implantation [21]. For hand-assisted laparoscopic surgery, Chen and collaborators [38] recommend using a watertight bag model, not enlarging the surgical wound if there is resistance when extracting the surgical specimen and changing gloves before wound closure in order to avoid contamination with malignant cells [38]. Port-site metastasis in urological laparoscopic surgery is rare. Several factors have been associated with tumor seeding, but tumor grade and stage appear to have the greatest importance. Nevertheless, risk can be minimized by applying open surgery oncologic procedural norms $[9,18-30]$.

\section{Conclusion}

Port-site metastasis in urological laparoscopic surgery is rare. Multiple factors have been associated with tumour seeding, but tumour grade and stage appear to play a major role. Multiple methods have been described to reduce the risk of port-site metastasis. The incidence is comparable to the rate for surgical wound metastases. 
TABLe 1: The case reports found on MEDLINE.

\begin{tabular}{|c|c|c|c|}
\hline Author & Procedure & Tumour type, stage, and grade & Number of cases \\
\hline Stolla et al., 1994 & Laparoscopic pelvic lymph node dissection & Bladder TCC pT3G2 & 1 \\
\hline Andersen et al.,1995 & Transperitoneal laparoscopic bladder biopsy & Bladder TCC T1G2 & 1 \\
\hline Bangma et al., 1995 & Laporoscopic pelvic lymph node dissection & PCa T3N1 & 1 \\
\hline Altieri et al., 1998 & Laporoscopic pelvic lymph node dissection & Bladder TCC T3G2 & 1 \\
\hline Ahmed et al., 1998 & Laparoscopic nephrectomy & Kidney TCC T3G3-G4 & 1 \\
\hline Otani et al., 1999 & Laparoscopic nephrectomy & $\begin{array}{l}\text { Incidental finding of TCC, G3 within tuberculous } \\
\text { atrophic kidney }\end{array}$ & 1 \\
\hline Fentie et al., 2000 & Laparoscopic nephrectomy & RCC T3N0G4 & 1 \\
\hline $\begin{array}{l}\text { Landman and } \\
\text { Clayman, } 2001\end{array}$ & Laparoscopic nephrectomy & RCC T1N0G2 & 1 \\
\hline Castilho et al., 2001 & Laparoscopic nephrectomy & RCC T1N0G2 & 1 \\
\hline Wang et al., 2002 & Laparoscopic cystectomy & Incidental finding of SCC in ovarian dermoid cyst & 1 \\
\hline Chen et al., 2003 & Laparoscopic nephrectomy (hand assisted) & RCC T2N0M0 & 1 \\
\hline \multirow[t]{2}{*}{ Rassweiler et al., 2003} & Laparoscopic adrenalectomy & Small-cell lung carcinoma adrenal metastasis & 1 \\
\hline & $\begin{array}{l}\text { Laparoscopic retroperitoneal lymph node } \\
\text { dissection }\end{array}$ & NA & 1 \\
\hline Saraiva P et al., 2003 & Laparoscopic adrenalectomy & $\begin{array}{l}\text { Metastatic melanoma of adrenal gland. Grade } \\
\text { unavailable }\end{array}$ & 1 \\
\hline Matsui et al., 2004 & $\begin{array}{l}\text { Laparoscopic retroperitoneal } \\
\text { nephroureterectomy }\end{array}$ & SCC pT3N0M0 & 1 \\
\hline Iwamura et al., 2004 & Laparoscopic retroperitoneal nephrectomy & RCC T1bN0M0 & 1 \\
\hline \multirow{5}{*}{ Micali et al., 2004} & Laparoscopic Adrenalectomy & $\begin{array}{l}\text { Lung metastases pT4/G3 (3); Adrenocortical } \\
\text { Ca-grade and stage NA (1) }\end{array}$ & 4 \\
\hline & Laporoscopic pelvic lymph node dissection & Squamous penile $\mathrm{Ca}$ & 1 \\
\hline & $\begin{array}{l}\text { Laparoscopic retroperitoneal lymph node } \\
\text { dissection }\end{array}$ & Nonseminomatous Germ Cell Tumor & 1 \\
\hline & Laparoscopic simple nephrectomy & $\begin{array}{l}\text { Incidental TCC in each instance-pT1/G2; } \\
\text { pT1/G3; pT2/G3; NA }\end{array}$ & 4 \\
\hline & Laparoscopic nephroureterectomy & $\mathrm{pT} 3 / \mathrm{G} 3$ & 3 \\
\hline Naderi et al., 2004 & Laporoscopic nephroureterectomy & Kidney TCC cT1N0M0 & 1 \\
\hline Chueh et al., 2004 & Laporoscopic bilateral nephroureterectomy & $\begin{array}{l}\text { Grade } 2 \text { renal TCC with pelvic muscular invasion } \\
\text { and bladder metastasis }\end{array}$ & 1 \\
\hline Porpiglea et al., 2004 & Laparoscopic adrenalectomy & $\begin{array}{l}\text { Adrenal metastasis from nonsmall cell lung } \\
\text { carcinoma }\end{array}$ & 1 \\
\hline $\begin{array}{l}\text { El-Tabey and Shoma, } \\
2005\end{array}$ & Laparoscopic cystectomy (robot-assisted) & Bladder TCC T3bN0M0G3 & 1 \\
\hline Kobori et al., 2005 & Laparoscopic nephrectomy & $\begin{array}{l}\text { Papillary adenocarcinoma of pelvis. Stage and } \\
\text { grade unavailable }\end{array}$ & 1 \\
\hline Dhobada et al., 2006 & Laparoscopic nephrectomy & RCC T2N0M0G3 & 1 \\
\hline Manabe et al., 2007 & Laparoscopic nephroureterectomy & $\begin{array}{l}\text { Upper tract transitional cell carcinoma without } \\
\text { distant metastases }\end{array}$ & 1 \\
\hline Muntener et al., 2007 & Laparoscopic radical nephroureterectomy & Upper tract TCC. Stage T1, high grade & 1 \\
\hline \multirow{2}{*}{$\begin{array}{l}\text { Castillo and } \\
\text { Vitagliano } 2008\end{array}$} & Laparoscopic partial nephrectomy & RCC T1N0M0G3 & 1 \\
\hline & $\begin{array}{l}\text { Laparoscopic retroperitoneal lymph node } \\
\text { dissection }\end{array}$ & Mixed germ cell tumor T3N0M0 & 1 \\
\hline Cresswell et al., 2008 & $\begin{array}{l}\text { Laporoscopic retroperitoneal lymph node } \\
\text { dissection }\end{array}$ & $\begin{array}{l}\text { Stage } 1 \text { nonseminomatous germ cell tumour. } \\
\text { Grade NA }\end{array}$ & 1 \\
\hline Segawa et al., 2008 & $\begin{array}{l}\text { Laparoscopic nephroureterectomy and } \\
\text { cystectomy }\end{array}$ & $\begin{array}{l}\text { Invasive bladder cancer with bone metastasis. } \\
\text { Grade NA }\end{array}$ & 1 \\
\hline
\end{tabular}


TABle 1: Continued.

\begin{tabular}{|c|c|c|c|}
\hline Author & Procedure & Tumour type, stage, and grade & Number of cases \\
\hline $\begin{array}{l}\text { Spermon and Witjes } \\
2008\end{array}$ & $\begin{array}{l}\text { Laparoscopic retroperitoneal lymph node } \\
\text { dissection }\end{array}$ & $\begin{array}{l}\text { Stage IIb non seminomatous germ cell tumour } \\
\text { (Histology-yolk sac and teratoma elements) }\end{array}$ & 1 \\
\hline Greco et al., 2009 & Laparoscopic partial nephrectomy & $\begin{array}{l}\text { Renal clear cell papillary carcinoma pT1a, high } \\
\text { grade }\end{array}$ & 1 \\
\hline Yasuda et al., 2009 & laparoscopic nephroureterectomy & $\begin{array}{l}\text { Upper urinary tract carcinoma. T2N0M0 Grade } 2 \\
>3\end{array}$ & 1 \\
\hline Huang et al., 2010 & $\begin{array}{l}\text { Laparoscopic radical cystectomy and pelvic } \\
\text { lymph node dissection }\end{array}$ & NA & 1 \\
\hline
\end{tabular}

$\mathrm{Pca}=$ prostate cancer, $\mathrm{RCC}=$ Renal cell carcinoma, SCC cell carcinoma, NA = not available .

\section{References}

[1] G. D. Stewart and D. A. Tolley, "What are the oncological risks of minimal access surgery for the treatment of urinary tract cancer?" European Urology, vol. 46, no. 4, pp. 415-420, 2004.

[2] G. Vitagliano, O. Castillo, J. M. Campero, I. Pinto, and M. Dİaz, "Laparoscopicretroperitoneal lymph node dissection for nonseminomatoustesticular cancer in stage T1 and T2," Journal of Endourology, vol. 20, supplement 1, abstract MP 2104, p. A235, 2006.

[3] G. Vitagliano, O. Castillo, I. Pinto, M. Dİaz, and M. Contreras, "Complications in laparoscopic transperitoneal partial nephrectomy," Journal of Endourology, vol. 20, supplement 1, abstract MP 2-15, p. A10, 2006.

[4] O. A. Castillo, G. Vitagliano, M. Díaz, and R. Sánchez-Salas, "Port-site metastasis after laparoscopic partial nephrectomy: case report and literature review," Journal of Endourology, vol. 21, no. 4, pp. 404-407, 2007.

[5] A. Rané, M. K. Eng, and F. X. Keeley, "Port site metastases," Current Opinion in Urology, vol. 18, no. 2, pp. 185-189, 2008.

[6] M. J. Curet, "Port site metastases," American Journal of Surgery, vol. 187, no. 6, pp. 705-712, 2004.

[7] Z. Dobronte, T. Wittman, and G. Karacsony, "Rapid development of malignant metastases in the abdominal wall after laparoscopy," Endoscopy, vol. 10, no. 2, pp. 127-130, 1978.

[8] S. Micali, A. Celia, P. Bove et al., "Tumor seeding in urological laparoscopy: an international survey," Journal of Urology, vol. 171, no. 6 I, pp. 2151-2154, 2004.

[9] A. Tsivian and A. A. Sidi, "Port site metastases in urological laparoscopic surgery," Journal of Urology, vol. 169, no. 4, pp. 1213-1218, 2003.

[10] J. Rassweiler, A. Tsivian, A. V. Ravi Kumar et al., "Oncological safety of laparoscopic surgery for urological malignancy: experience with more than 1,000 operations," Journal of Urology, vol. 169, no. 6, pp. 2072-2075, 2003.

[11] P. Fornara, "Port site metastases: fact or fiction?" Urologe A, vol. 41, no. 2, pp. 113-119, 2002.

[12] Y. W. Novitsky, D. E. M. Litwin, and M. P. Callery, "The net immunologic advantage of laparoscopic surgery," Surgical Endoscopy and Other Interventional Techniques, vol. 18, no. 10, pp. 1411-1419, 2004.

[13] R. A. Highshaw, F. Vakar-Lopez, E. Jonasch, A. W. Yasko, and S. F. Matin, "Port-site metastasis: the influence of biology," European Urology, vol. 47, no. 3, pp. 357-360, 2005.

[14] M. W. Wichmann, T. P. Hüttl, H. Winter et al., "Immunological effects of laparoscopic vs open colorectal surgery. A prospective clinical study," Archives of Surgery, vol. 140, no. 7, pp. 692-697, 2005.
[15] M. C. Ost, B. J. Tan, and B. R. Lee, "Urological laparoscopy: basic physiological considerations and immunological consequences," Journal of Urology, vol. 174, no. 4 I, pp. 1183-1188, 2005.

[16] P. Sylla, I. Kirman, and R. L. Whelan, "Immunological advantages of advanced laparoscopy," Surgical Clinics of North America, vol. 85, no. 1, pp. 1-18, 2005.

[17] E. Kuhry, J. Jeekel, and H. J. Bonjer, "Effect of laparoscopy on the immune system," Seminars in Laparoscopic Surgery, vol. 11, no. 1, pp. 37-44, 2004.

[18] S. Ikramuddin, J. Lucas, E. C. Ellison, W. J. Schirmer, and W. S. Melvin, "Detection of aerosolized cells during carbon dioxide laparoscopy," Journal of Gastrointestinal Surgery, vol. 2, no. 6, pp. 580-584, 1998.

[19] C. Jingli, C. Rong, and X. Rubai, "Influence of colorectal laparoscopic surgery on dissemination and seeding of tumor cells," Surgical Endoscopy and Other Interventional Techniques, vol. 20, no. 11, pp. 1759-1761, 2006.

[20] A. Tsivian, A. Shtabsky, J. Issakov, M. Gutman, A. A. Sidi, and A. Szold, "The effect of pneumoperitoneum on dissemination and scar implantation of intra-abdominal tumor cells," Journal of Urology, vol. 164, no. 6, pp. 2096-2098, 2000.

[21] J. M. Burns, B. D. Matthews, H. S. Pollinger et al., "Effect of carbon dioxide pneumoperitoneum and wound closure technique on port site tumor implantation in a rat model," Surgical Endoscopy and Other Interventional Techniques, vol. 19, no. 3, pp. 441-447, 2005.

[22] V. J. Halpin, R. A. Underwood, D. Ye et al., "Pneumoperitoneum does not influence trocar site implantation during tumor manipulation in a solid tumor model," Surgical Endoscopy and Other Interventional Techniques, vol. 19, no. 12, pp. 1636-1640, 2005.

[23] A. Gupta, D. I. Watson, T. Ellis, and G. G. Jamieson, "Tumour implantation following laparoscopy using different insufflation gases," ANZ Journal of Surgery, vol. 72, no. 4, pp. 254-257, 2002.

[24] D. Mutter, A. Hajri, V. Tassetti, C. Solis-Caxaj, M. Aprahamian, and J. Marescaux, "Increased tumor growth and spread after laparoscopy vs laparotomy: influence of tumor manipulation in a rat model," Surgical Endoscopy, vol. 13, no. 4, pp. 365-370, 1999.

[25] S. W. Lee, R. L. Whelan, J. C. Southall, and M. Bessler, "Abdominal wound tumor recurrence after open and laparoscopic-assisted splenectomy in a murine model," Diseases of the Colon and Rectum, vol. 41, no. 7, pp. 824-831, 1998.

[26] S. W. Lee, N. R. Gleason, M. Bessler, and R. L. Whelan, "Port site tumor recurrence rates in a murine model of laparoscopic 
splenectomy decreased with increased experience," Surgical Endoscopy, vol. 14, no. 9, pp. 805-811, 2000.

[27] J. T. Bishoff, "Laparoscopic radical nephrectomy: morcellate or leave intact? Definitely morcellate!," Reviews in Urology, vol. 4, no. 1, pp. 34-37, 2002.

[28] I. Varkarakis, K. Rha, F. Hernandez, L. R. Kavoussi, and T. W. Jarrett, "Laparoscopic specimen extraction: morcellation," British Journal of Urology International, Supplement, vol. 95, no. 2, pp. 27-31, 2005.

[29] M. V. Meng, T. R. Miller, I. Cha, and M. L. Stoller, "Cytology of morcellated renal specimens: significance in diagnosis and dissemination," Journal of Urology, vol. 169, no. 1, pp. 45-48, 2003.

[30] A. L. Shalhav, I. Leibovitch, R. Lev, D. M. Hoenig, and J. Ramon, "Is laparoscopic radical nephrectomy with specimen morcellation acceptable cancer surgery?" Journal of Endourology, vol. 12, no. 3, pp. 255-257, 1998.

[31] S. Kinugasa, E. Smith, P. A. Drew, D. I. Watson, and G. G. Jamieson, "Aspirin and indomethacin for the prevention of experimental port-site metastases," Surgical Endoscopy and Other Interventional Techniques, vol. 18, no. 5, pp. 834-838, 2004.

[32] P. Wittich, A. Mearadji, R. L. Marquet, and H. J. Bonjer, "Irrigation of port sites: prevention of port site metastases?" Journal of Laparoendoscopic and Advanced Surgical Techniques $A$, vol. 14, no. 3, pp. 125-129, 2004.

[33] W. A. A. Tjalma, "Laparoscopic surgery and port-site metastases: routine measurements to reduce the risk," European Journal of Gynaecological Oncology, vol. 24, no. 3-4, p. 236, 2003.

[34] R. Steinert, H. Lippert, and M. A. Reymond, "Tumor cell dissemination during laparoscopy: prevention and therapeutic opportunities," Digestive Surgery, vol. 19, no. 6, pp. 464-472, 2002.

[35] A. Agostini, S. Mattei, I. Ronda et al., "Prevention of portsite metastasis after laparoscopy," Gynécologie, Obstétrique \& Fertilité, vol. 30, pp. 878-881, 2002.

[36] M. Pross, H. Lippert, G. Nestler et al., "Effect of low molecular weight heparin on intra-abdominal metastasis in a laparoscopic experimental study," International Journal of Colorectal Disease, vol. 19, no. 2, pp. 143-146, 2004.

[37] C. Schneider, A. Jung, M. A. Reymond et al., "Efficacy of surgical measures in preventing port-site recurrences in a porcine model," Surgical Endoscopy, vol. 15, no. 2, pp. 121125, 2001.

[38] Y. T. Chen, S. S. D. Yang, C. H. Hsieh, and C. C. Wang, "Hand port-site metastasis of renal-cell carcinoma following hand-assisted laparoscopic radical nephrectomy: case report," Journal of Endourology, vol. 17, no. 9, pp. 771-773, 2003. 


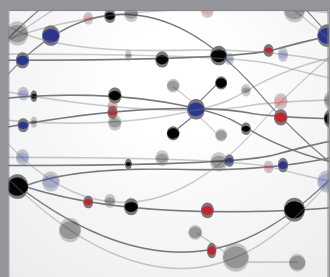

The Scientific World Journal
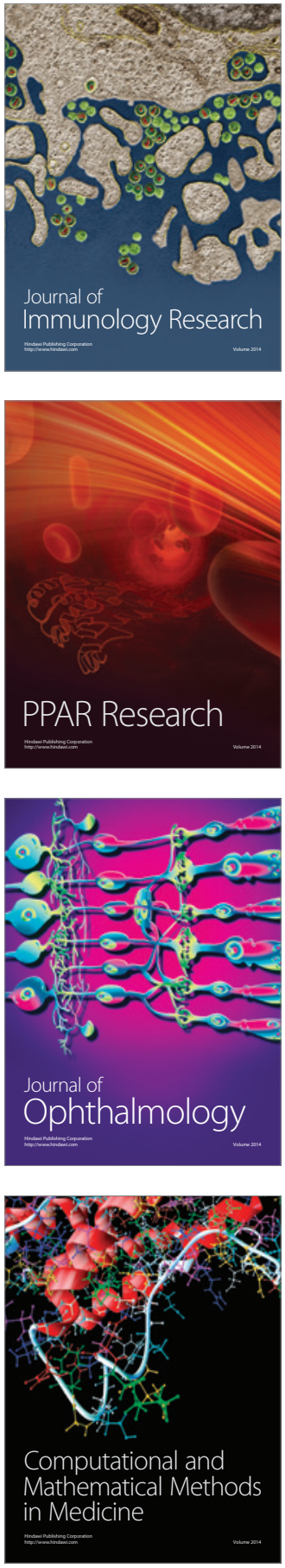

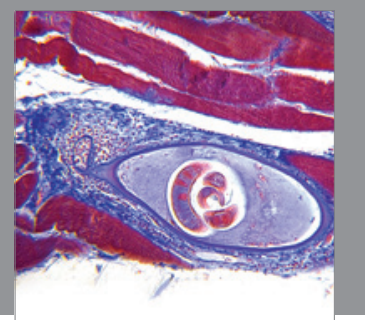

Gastroenterology

Research and Practice
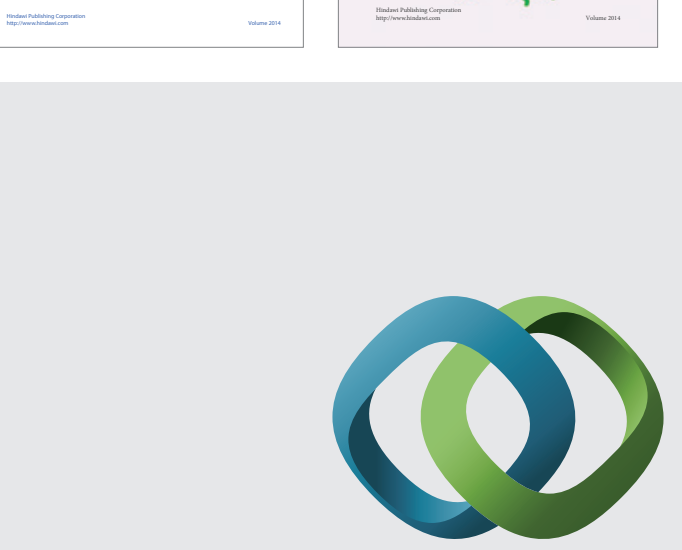

\section{Hindawi}

Submit your manuscripts at

http://www.hindawi.com
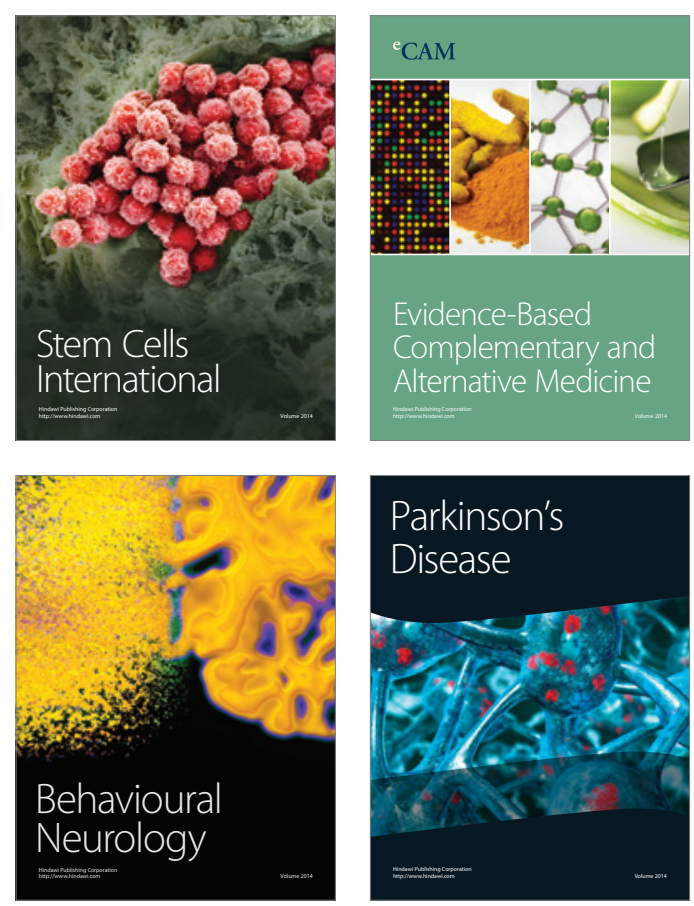

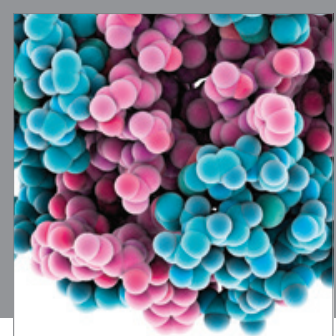

Journal of
Diabetes Research

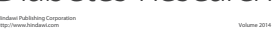

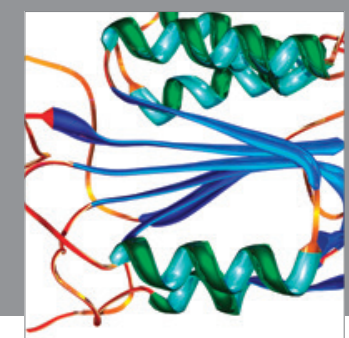

Disease Markers
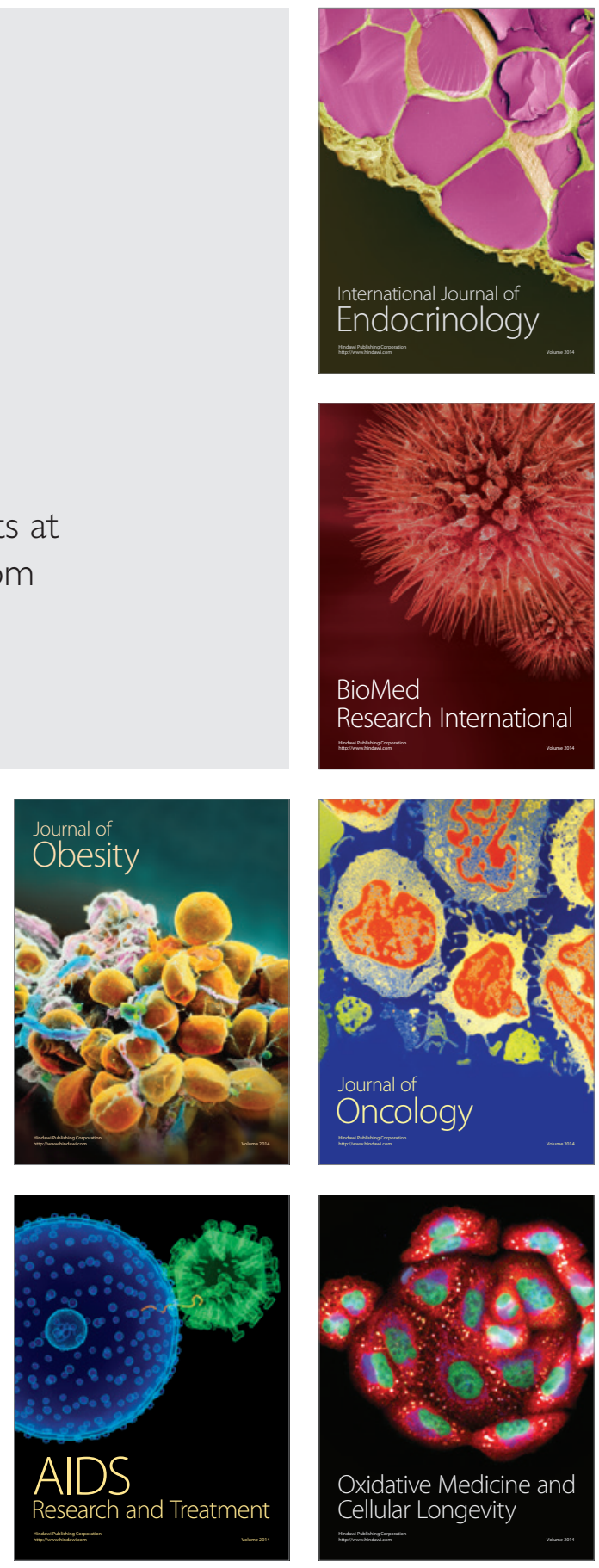